\title{
Active T Rosette Formation of Human T Lymphocytes after Stimulation with Lectins
}

\author{
Kyoichi Ohkubo', Carolyn Curtis Huntenburg ${ }^{2}$, Keiji OhKubo ${ }^{3}$, Shinji Kurimoto' \\ and M. Mitsuo YoKOYAMA ${ }^{3}$ \\ ${ }^{1}$ Department of Ophthalmology, School of Medicine, University of Occupational and \\ Environmental Health, Japan. Kitakyushu 807, Japan \\ ${ }^{2}$ Department of Pathology and Microbiology, University of Illinois Medical Center \\ Chicago. Illinois 60612, U. S. A. \\ ${ }^{3}$ Department of Immunology, Kurume University School of Medicine. Kurume 830, Japan
}

\begin{abstract}
The effect of fourteen plant lectins on human peripheral blood lymphocytes in rosette formation with sheep red blood cells (SRBC) was examined. Among the lectins used, phytohemagglutinin (PHA), lens culinalis (LCH), wheat germ agglutinin (WGA), and ricinus communis I (RCAI) showed a significant increase in active $\mathrm{T}$ rosette counts when the results were compared with the effect of other lectins. This enhancement in active $\mathrm{T}$ rosette forming cells is found within one hour after the treatment with lectin and is dependent upon the concentration of lectin. The results suggest that the changes in lymphocyte membrane dynamics via stimulation by certain lectins increases the capacity to form active $T$ rosettes.
\end{abstract}

Key words: human $\mathrm{T}$ lymphocyte, sheep red blood cell, active $\mathrm{T}$ rosette formation, lectin.

(Received 15 May 1984)

\section{Introduction}

Human $T$ lymphocytes can be identified by their ability to bind sheep red blood cells (SRBC) non-immunologically (Fröland, 1972; Jondal et al., 1972) and can be further divided into two categories to form spontaneous rosettes which may be caused by a difference of affinity. T lymphocytes that display a higher affinity for SRBC and form rosettes within a shorter incubation period are desingnated "active" $\mathrm{T}$ lymphocytes, while a longer incubation is required for "total" $\mathrm{T}$ lymphocytes which have a lower affinity for SRBC (Stites, 1980).

Lymphocytes can be induced to proliferate in vitro by specific antigens and allogeneic cells (Robbins, 1964). The mechanism of amplification is difficult to elucidate because of the small percentage of cells that actually respond to a specific antigen (Ada, 1970; Simonsen, 1967). To overcome this difficulty, polyclonal ligands or mitogens, which stimulate lymphocytes non-specifically, are used (Hume \& Weidemann, 1980). The most commonly used mitogens are carbohydrate-binding plant lectins. A proposed function of carbohydrate binding lectins would enable them to play a role in both intracellular and intercellular recognition (Chang et al., 1975; Bowles \& Kauss, 1976; Rosen et al., 1976; 
Ashwell, \& Morell, 1977), since they have been reported to be present in cell membranes (Kieda et al., 1978; Kolb \& Kolb-Bachofen, 1978).

In this paper, the authors described how the effect of various lectins on the ability of human $\mathrm{T}$ lymphocytes to form active $\mathrm{T}$ rosettes was investigated, and a significant increase of active $\mathrm{T}$ rosette forming cells ( $\mathrm{T}-\mathrm{RFC}$ ) was found when the lymphocytes were treated with any of PHA, LCH, WGA or RCAI.

\section{Materials and Methods}

Isolation of peripheral blood lymphocytes

Heparinized human peripheral blood was collected from the laboratory staff. The blood was aseptically diluted with RPMI-1640 (Gibco, Grand Island, New York) and layered over Ficoll-paque (specific gravity 1.077, Pharmacia Chemicals Inc., Piscataway, New Jersey) in $16 \times 125 \mathrm{~mm}$ plastic round bottom centrifuge tubes (Falcon Plastics, Los Angeles, California). The tubes were centrifuged at $400 \times \mathrm{g}$ at room temperature for 30 minutes. The lymphocyte interface was collected, washed 3 times and resuspended in a complete medium: RPMI-1640 with 10\% fetal calf serum (FGS, General Scientific Laboratories, Los Angeles, California) and penicillin-streptomycin, (P-S, 1000 units $/ \mathrm{ml}-1000 \mu \mathrm{g} /$ ml, Gibco, Grand Island, New York).

\section{Active $T$ rosette assay}

The active $\mathrm{T}$ rosette test was performed by mixing an equal volume of the lectin treated lymphocytes and $0.5 \%$ of sheep red blood cells (SRBC, B. B. L., Cockeysville, Maryland) in a complete medium. The lymphocytes-SRBC mixture was incubated for one hour at $37^{\circ} \mathrm{C}$, centrifuged at $150 \times \mathrm{g}$ for 5 minutes and gently resuspended. Three hundred of cells were counted by microscopic observation and the percentage of rosette forming cells was determined.

Culturing lymphocytes with lectins

Lymphocytes were used at a concentration of $6.0 \times 10^{6}$ cells in a complete medium. The final lectin concentrations for concanavalin A (Con A), peanut agglutinin (PNA), lens culinalis (LCH), ulex europeus agglutinin (UEA), (Sigma, St. Louis, Missouri), wheat germ agglutinin (WGA), ricinus communis agglutinin I (RCAI), ricinus communis agglutinin II (RCAII), vicia faba agglutinin (VFA), vicia villosa agglutinin (VVA), soybean agglutinin (SBA), sarothamnus scoparius (SRA), bauhinia purpurea agglutinin (BPA), (E-Y Labs Inc., San Mateo, California) were 2 and $10 \mu \mathrm{g} / \mathrm{ml}$, respectively. Phytohemagglutinin (PHA, Welcom, Beckenham, England) and Pokeweed mitogen (PWM, Gibco, Grand Island, New York) were used at dilutions of 1:100 and $1: 1000$, in a complete medium. The cell-lectin suspension was incubated at $37^{\circ} \mathrm{C}$ in a $\mathrm{CO}_{2}$ incubator. 
In the time course study, cells were sampled at 30 minutes, 1, 4, 8, 12, 16, 20 and 24 hours. The percentage of active T-RFG was determined at each time assayed. In the dose response studies, PHA, LCH, WAG and RCAI were tested. PHA was diluted $1: 50,1: 100,1: 500$ and $1: 1000$ in a complete medium. The assay was then performed as described above. The final concentrations of LCH were 2, 10, 30 and 50 $\mu \mathrm{g} / \mathrm{ml}$. WGA was tested at 2, 10 and $45 \mu \mathrm{g} / \mathrm{ml}$. RCAI was diluted to 0.1, 1.0 and $10 \mu \mathrm{g} / \mathrm{ml}$.

The similar experiments were also performed after removing the lectin; the lectin stimulated lymphocytes were washed 3 times by RPMI-1640 and the active T rosette formation (active TRF) was assayed.

In all experiments, lymphocytes were incubated in a complete medium as a control. The control was processed in the same way as the experimental in each case. Cell viability was determined by trypan blue dye exclusion at the time of the rosette assay.

All above procedures were repeated more than 4 times. All statistical analyses were performed by utilizing the statistics program available for the Texas Instrument 99/4 Home Computer.

\section{Results}

Lymphocytes were incubated with various lectins for several hours and the formation of active $\mathrm{T}$ rosettes was assayed.

Fig. 1 shows the effect of PHA on active TRF. PHA significantly increased active TRF and the maximum response was observed at a dilution of $1: 50$. The viability of lymphocytes treated with PHA at 1:50 dilution was somewhat decreased (70\%), while all other concentrations did not change in viabilities $(90 \%)$ as determined by trypan blue exclusion. PHA at $1: 50$ and $1: 100$ dilution significantly enhanced active TRF within one hour of incubation (Student t, $P<0.02$ ), and the percentage of active T-RFC after one hour PHA stimulation was comparable to the total T-RFC.

Fig. 2 shows the effect of LCH on active TRF. The effect of LCH was dose dependent and maximum response was observed at the concentration of $50 \mu \mathrm{g} / \mathrm{ml}$. The viability of lymphocytes treated with $50 \mu \mathrm{g} / \mathrm{ml}$ of LCH was somewhat decreased $(73 \%)$, whereas in all other concentrations the viability was not changed $(90 \%)$. LCH at a concentration of 10 and $30 \mu \mathrm{g} / \mathrm{ml}$, exhibited significant enhancement of active TRF (Student $\mathrm{t}, P<0.02$ ) within one hour of incubation.

Fig. 3 shows the effect of WGA on active TRF. The effect of WGA was dose dependent and the maximum response was observed at a concentration of $45 \mu \mathrm{g} /$ $\mathrm{ml}$. The viability of lymphocytes treated with $45 \mu \mathrm{g} / \mathrm{ml}$ of WGA was somewhat decreased $(72 \%)$, whereas in all other concentrations the viability was not changed $(90 \%)$. WGA, at a concentration of $10 \mu \mathrm{g} / \mathrm{ml}$, significantly enhanced active TRF (Stu- 


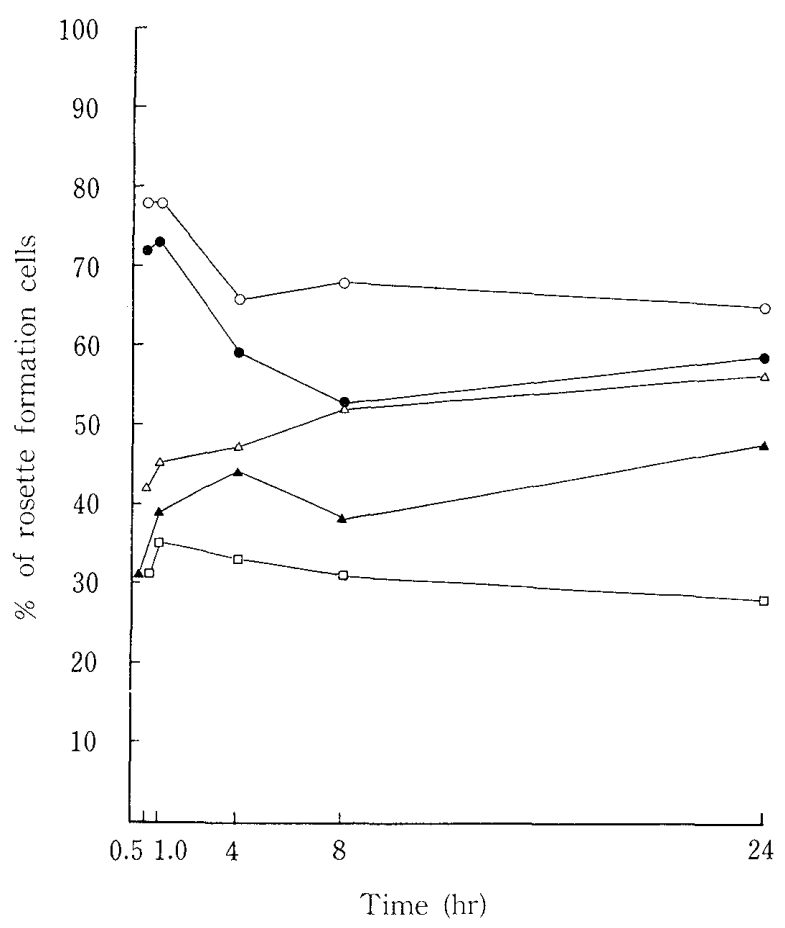

Fig. 1. Effect of PHA on active $\mathrm{T}$ rosette formation. PHA was used at a dilution of 1: 50(O), $1: 100(\bullet), 1: 500(\Delta), 1: 1000(\mathbf{\Delta})$. $(\square)$ is control.

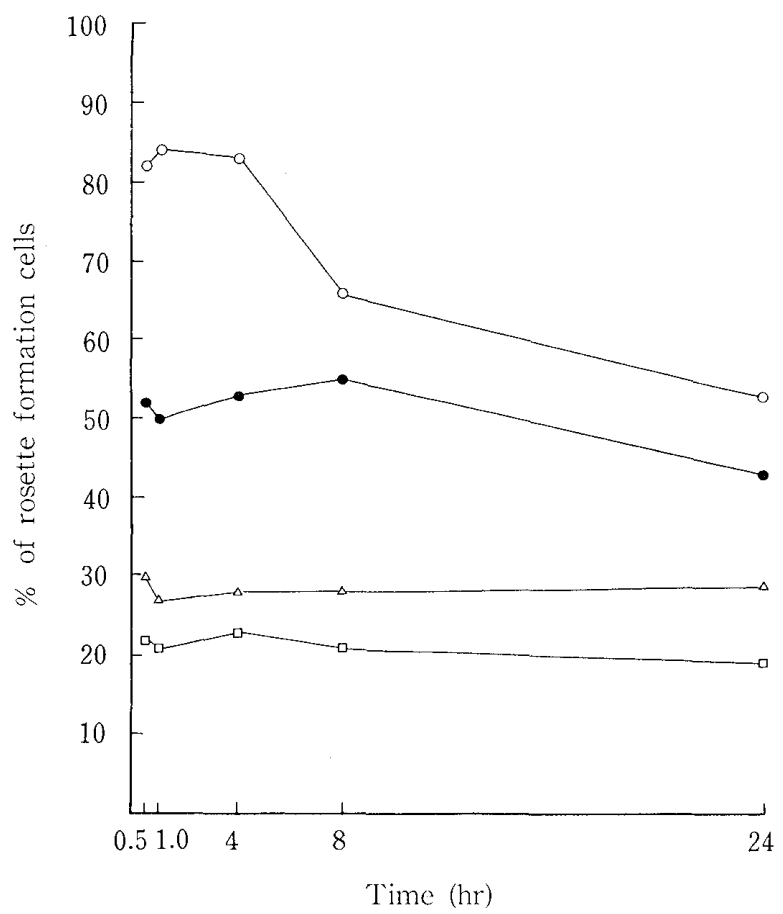

Fig. 3. Effect of WGA on active $\mathrm{T}$ rosette formation. Concentrations of WGA were $45 \mu \mathrm{g} / \mathrm{ml}(0)$, $10 \mu \mathrm{g} / \mathrm{ml}(\bullet)$ and $2 \mu \mathrm{g} / \mathrm{ml}(\Delta)$.

$(\square)$ is control.

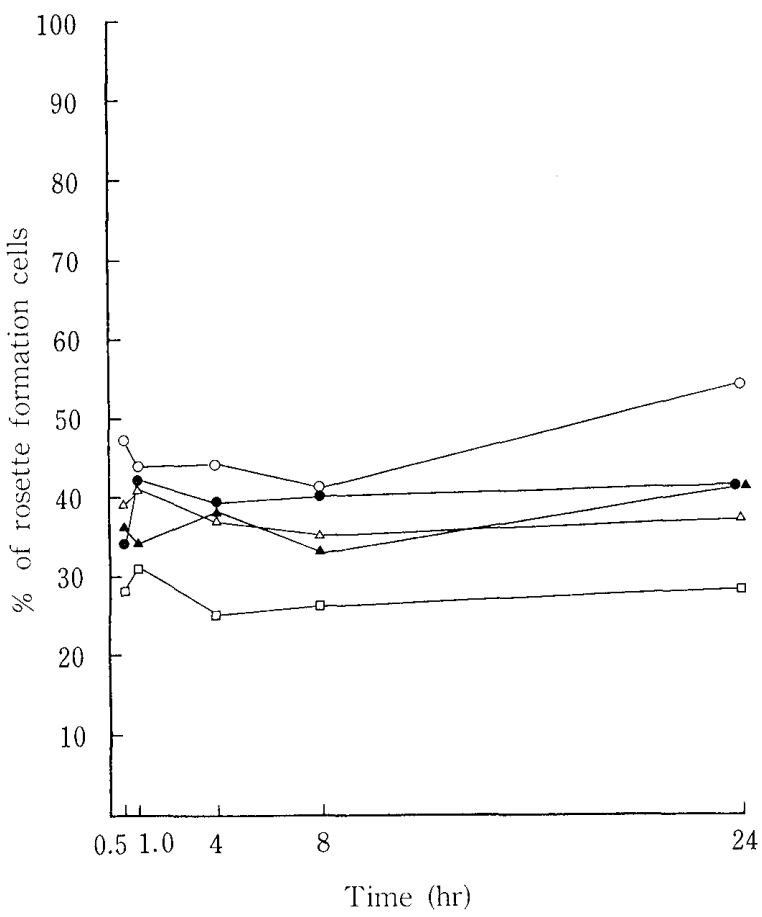

Fig. 2. Effect of $\mathrm{LCH}$ on active $\mathrm{T}$ rosette formation. Concentrations of LCH were $50 \mu \mathrm{g} / \mathrm{ml}(\bigcirc)$, $30 \mu \mathrm{g} / \mathrm{ml}(\bullet), 10 \mu \mathrm{g} / \mathrm{ml}(\triangle)$ and $2 \mu \mathrm{g} / \mathrm{ml}(\bullet)$. $(\square)$ is control.

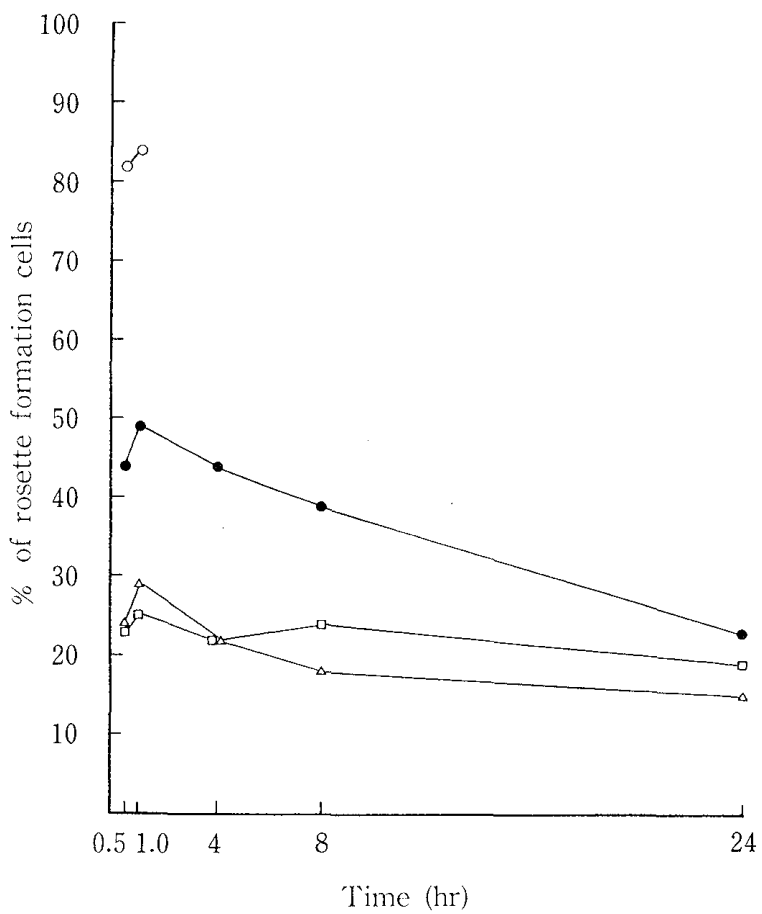

Fig. 4. Effect of RCAI on active $T$ rosette formation. Concentrations of RCAI were $10 \mu \mathrm{g} / \mathrm{ml}(\mathrm{O})$, $1.0 \mu \mathrm{g} / \mathrm{ml}(\bullet)$ and $0.1 \mu \mathrm{g} / \mathrm{ml}(\triangle)$. (ㅁ) is control. 
dent t, $P<0.005)$ within one hour of incubation.

Fig. 4 shows the effect of RCAI on active TRF. RCAI was cytotoxic at a concentration of $\geqq 10 \mu \mathrm{g} / \mathrm{ml}$ as detected by a decrease in cell viability $(<30 \%$ after 30 minutes incubation). RGAI at a concentration of $1.0 \mu \mathrm{g} / \mathrm{ml}$ exhibited significant enhancement of active TRF (Student $\mathrm{t}, P<0.05$ ) whereas $0.1 \mu \mathrm{g} / \mathrm{ml}$ of RCAI did not. This increase of active TRF was observed within one hour of incubation. RCAI, at a concentration of $1.0 \mu \mathrm{g} / \mathrm{ml}$, was cytotoxic and after 12 hours of culture, cell viability had decreased to $68 \%$ of the original level.

All other lectins, Con A, PNA, UEA, RCAII, VFA, VVA, SBA, SRA, BPA and PWM, at concentrations tested, showed no significant effect on active TRF when compared with control.

\section{Discussion}

In this study, it was shown that activation of peripheral blood lymphocytes with plant lectins induced an enhanced active TRF. Of the lectins assayed, PHA, LCH, WGA and RCAI exhibited an effect on active TRF. PHA and LCH have an affinity for N-acetylD-galactosamine (Borberg et al., 1966, 1968) and $\alpha$-D-mannose, $\alpha$-D-glucose (Lis \& Sharon, 1977; Weir, 1980), respectively and have been shown to be primarily $\mathrm{T}$ cell mitogens in lymphocyte stimulation, when assayed for the uptake of tritiated thymidine (Lis \& Sharon, 1977). Con A with a sugar specificities of $\alpha$-methyl-D-mannoside and $\alpha$-D-glucopyranosides (Goldstein et al., 1974) is also a $\mathrm{T}$ cell activating mitogen (Douglas et al., 1969; Powell \& Leon, 1970), but had no enhancing effect on active TRF. WGA and RCAI with sugar specificities of (GlcNAc) 2 and $\beta$-D-Galactose (Weir, 1980) are nonmitogenic plant lectins (Lis \& Sharon, 1977). However, both lectins exhibited enhanced active TRF. These results indicated that the mitogenicity of the lectin is not a factor in the enhancement of active TRF. This is in direct contrast with the results of Richie \& Patchen (1978), who reported that when human peripheral blood lymphocytes were assayed for temperature stable rosette after pretreatment with lectins, only cells that were incubated with PHA and Con A showed increased active TRF whereas WGA had no effect.

The lectins which induce enhanced active TRF have been reported to bind specific sugars (Lis \& Sharon, 1977; Weir, 1980) and the relationship between these binding specificities and the increased percentage of active TRF was investigated. We found through our experiments that lectins which increase active TRF do not have sugar specificities indicating that sugar specificity is not a factor in increased active TRF.

The binding of lectins to cell membranes can be affected by several conditions such as concentrations, $\mathrm{pH}$, and the time and temperature of activation (Lis \& Sharon, 1977). It was determined that a dose response existed for PHA, LCH, WGA and RCAI. In other studies (Lis \& Sharon, 1977), it is reported that the concentrations of 
lectins more than $100 \mu \mathrm{g} / \mathrm{ml}$ showed no activation of lymphocytes. These results are in agreement with our experiments. In each case, we observed that an increase of active TRF parallels with the concentration of lectins. However, when the concentrations of lectin more than maximum enhancement was used, the cell were agglutinated and the viability was decreased and we could not detect enhanced active TRF.

In addition to the effect of lectin concentration on active TRF, we also observed that lectin activation of lymphocytes was somewhat time dependent. A certain concentration of PHA, LCH, WGA and RCAI showed significant increase of active TRF within one hour of incubation. The early effect on active TRF may suggest membrane alteration since cellular changes occur very early in lymphocyte after the addition of a mitogen, some of them within seconds to minutes. The earliest detectable changes are in the membrane including increased membrane permiability and accelerated turnover of membrance phospholipids. Other cellular responses to mitogenic stimulation are RNA and protein synthesis, which is induced 10-20 hours after stimulation, and DNA synthesis, which results in 48 hours after mitogen activation, as reviewed by Wedner \& Parker (1976).

The experiment of removing lectins from the cell after short treatment was also examined. The results indicated that removing the lectins from the cell suspension had no effect on the active TRF induced by PHA, LCH, WGA or RCAI. It has been reported that lymphocytes are committed to DNA synthesis even when surface-bound mitogen is removed 24 hours prior to the initiation of DNA synthesis (Powell \& Leon, 1970; Stein et al., 1972; Gunther et al., 1974), which is complimentary to the results of rosette assay observed in our experiment.

Throughout the study, the count of active T-RFC obtained in response to PHA and WGA stimulation was similar to that of the total T-RFC $(65-75 \%)$. Within a total population of lymphocytes, each subclass or subpopulation may differ in their response to different mitogens. An example is a mouse thymocyte. The immature thymocyte subpopulation which is comprised of $90-95 \%$ thymocytes and sensitive to cortison and radiation-treatment, are stimulated by Con A but not by PHA, whereas the mature thymocyte subpopulation which is resistant to cortisone and radiation-treatment responds to both of these mitogens (Stobo et al., 1972).

It is known that lymphocytes bind $10^{6}-10^{7}$ lectin molecules per cell, regardless of the sort of lectin (Lis \& Sharon, 1977; Sharon \& Lis, 1975). There is no difference in the number of binding sites between the cells that agglutinate and those that do not (Sharon \& Lis, 1975). In our experiments, not all lectins exhibited increased active T-RFC counts. PHA has been documented to promptly increase membrane fluidity (Barnett $e t$ al., 1974) which may allow additional SRBC receptors to be expressed on the membrane. The mechanism of lymphocyte stimulation by lectin is presently unknown, however it is hypothesized to be a 2 signal effect. The actual binding of lectin to the cell is the first signal and this binding leads to membrane modification which in turn triggers the second signal, the biochemical events (Lis \& Sharon, 1977). 
The biological function of active $\mathrm{T}$ rosettes are not known, but they may express the activation process for the effector population in vivo.

\section{Acknowledgement}

This work was supported by a research grant from Nihon Reizo, Co. Ltd., Tokyo, Japan, and the authors wish to express their appreciation to Robert Milligan, General Scientific Laboratories, Los Angeles, California, for his generous support of our present study by supplying FCS.

\section{References}

Ada, G. L. (1970): Antigen-binding cells in tolerance and immunity. Transplant. Rev., 5: 105-129.

Ashwell, G. \& Morell, A. G. (1977): Membrane glycoproteins and recognition phenomena. Trends Biochem. Sci., 2: 76-78.

Barnett, R. E., Scott, R. E., Furcht, L. T. et al. (1974): Evidence that mitogenic lectins induce changes in lymphocyte membrane fluidity. Nature, 249: 465-466.

Borberg, H., Woodruff, J., Hirschhorn, R. et al. (1966): Phytohemagglutinin; Inhibition of the agglutinating activity by N-acetyl-D-galactosamine. Science, 154: 1019-1020.

Borberg, H., Yesner, I., Gesner, B. et al. (1968): The effect of $\mathrm{N}$ acetyl D-galactosamine and other sugars on the mitogenic activity and attachment of PHA to tonsil cells. Blood, 31: 747-757.

Bowles, D. J., \& Kauss, H. (1976): Characterization, enzymatic and lectin properties of isolated membranes from phaseolus-aureus. Biochem. Biophys. Acta, 443: 360-374.

Chang, C. M., Reitherman, R. W., Rosen, S. D. et al. (1975): Cell surface location of discoidin, a developmentally regulated carbohydrate-binding protein from Dictyostelium discoideum. Exp. Cell. Res., 95: 136-142.

Douglas, S. D., Kamin, R. M., Davis, W. C. et al. (1969): Biochemical and morphologic aspects phytomitogens: Jack bean, wax bean, pokeweed and phytohemagglutinin. Proc. Annu. Leukocyte Cult. Conf., 3: 607-621.

Fröland, S. S. (1972): Binding of sheep erythrocytes to human lymphocytes. A probable marker of T lymphocytes. Scand. J. Immunol., 1: 269-280.

Goldstein, I. J., Reichert, C. M. \& Misaki, A. (1974): Interaction of concanavalin A with model substrates. Ann. N. Y. Acad. Sci., 234: 283-296.

Gunther, G. R., Wang, J. L. \& Edelman, G. M. (1974): The Kinetics of cellular commitment during stimulation of lymphocytes by lectins. J. Cell Biol., 62: 366-377.

Hume, D. A. \& Weidemann, M. J. (1980): Lymphocyte mitogenesis-its relationship to other examples of anabolic cell activation. In: Mitogenic Lymphocyte Transformation. (Hume, D. A. \& Weidemann, M. J., ed.). Elsevier/North-Holland Biomedical Press, Amsterdam. pp. 1-19.

Jondal, M., Holm, G. \& Wigzell, H. (1972): Surface markers on human T and B lymphocytes. I. A large population of lymphocytes forming nonimmune rosettes with sheep red blood cells. J. Exp. Med., 136: 207-215.

Kieda, C. M. T., Bowles, D. J., Ravid, A. et al. (1978): Lectins in lymphocyte membranes. FEBS Lett., 94: $391-396$.

Kolb, H. \& Kolb-Bachofen, V. (1978): A lectin-like receptor on mammalian macrophages Biochem. Biophys. Res. Commun., 85: 678-683.

Lis, H. \& Sharon, N. (1977): Lectins: Their chemistry and application to immunology. In: The Anti- 
gens. Vol. IV. (Sela, M., ed.). Academic Press, New York. pp. 465-502.

Powell, A. E. \& Leon, M. A. (1970): Reversible interaction of human lymphocytes with the mitogen concanavalin A. Exp. Cell Res., 62: 315-325.

Richie, E. \& Patchen, M. (1978): Correlation between temperature-stable E-rosette formation and lymphocyte commitment to activation. Clin. Immunol. Immunopath., 11: 88-97.

Robbins, J. H. (1964): Tissue culture studies of the human lymphocyte. Science, 146: 1648-1654.

Rosen, S. D., Haywood, P. L. \& Barondes, S. H. (1976): Inhibition of intercellular adhesion in a cellular slime mould by univalent antibody against a cell surface lectin. Nature, 263: 425-427.

Sharon, N. \& Lis, H. (1975): Use of lectins for the study of membranes. Methods Membr. Biol., 3: $147-168$

Simonsen, M. (1967): The clonal selection hypothesis evaluated by grafted cells reacting against their hosts. Cold Spring Harbor Symp. Quant. Biol., 32: 517-523.

Stein, M. D., Sage, H. J. \& Leon, M. A. (1972): Studies on a phytohemagglutinin from the common lentil : VI. Stimulation of human peripheral lymphocytes in culture by Lens culinaris hemagglutinin A. Exp. Cell Res., 75: 475-482.

Stites, D. P. (1980): Clinical laboratory methods of detecting cellular immune function. In: Basic and Clinical Immunology. 3rd ed. (Fudenberg, H. H., Stites, D. P., Caldwell, J. L. et al., ed.). Lange Med. Pub., Los Altos, Ca. pp. 382-397.

Stobo, J. D., Rosenthal, A. S. \& Paul, W. E. (1972): Functional heterogeneity of murine lymphoid cells. I. Responsiveness and surface binding of concanavalin A and phytohemagglutitin. J. Immunol., 108: 1-17.

Wedner, H. J. \& Parker, C. W. (1976): Lymphocyte activation. Prog. Allergy, 20: 195-300.

Weir, D. M. (1980): Surface carbohydrate and lectins in cellular recognition. Immunol. Today, 1: 45-51.

\section{ヒト末梢血 Tリンパ球の Active T Rosette Formation に 及ぼすレクチンの影響}

大久保 享一 ${ }^{1}$ Carolyn Curtis $\mathrm{HUNTENBURG}^{2} \cdot$ 大久保 慶二 ${ }^{3} \cdot$ 栗本 $^{\text {晋二 }}{ }^{1} \cdot$ 横山 三男 $^{3}$ 産業医科大学眼科学教室 2イリノイ大学医学部病理学教室 ${ }^{3}$ 久留米大学医学部免疫学教室

要旨：ヒト末梢血 Tリンパ球 (human peripheral T lymphocyte; HTL) は, ヒツジ赤血球 (sheep red blood cell; SRBC) と rosetteを形成することが知られている。我々は，HTLを種々 のレクチンで刺激した場合の HTL と SRBCとの rosette 形成について研究を行った. 実 験に用いたレクチンは14 種類で, rosette assay は, active $\mathrm{T}$ rosette formation (active TRF)で行った。その結果，使用した 14 種類のレクチンのうち, active TRF の形成率が 上昇したものは，PHA，LCH，WGA およびRCAIの4 種類のみであり，これらの形成率 の上昇は, HTL を各レクチンで刺激した後 1 時間以内に観察され, また, 形成率の上昇 は,レクチンの濃度によっても影響された。また, active TRF の形成率の上昇作用は, 従来言われていた mitogenic lectin のみでなく, non-mitogenic lectinでも認められるこ とが判明し，レクチンの糖特異性とも特に密接な関係がないことが判明した。 